\title{
Molecular characteristics and expression of calmodulin cDNA from the freshwater pearl mussel, Hyriopsis schlegelii
}

\author{
L.-G. Zeng, J.-H. Wang, Y.-J. Li, J.-Q. Sheng, Q. Gu and Y.-J. Hong \\ College of Life Science and Food Engineering, Institute of Life Science, \\ Nanchang University, Nanchang, China \\ Corresponding author: Y.-J. Hong \\ E-mail: yjhong816@yahoo.com.cn
}

Genet. Mol. Res. 11 (1): 42-52 (2012)

Received March 31, 2011

Accepted July 19, 2011

Published January 9, 2012

DOI http://dx.doi.org/10.4238/2012.January.9.5

\begin{abstract}
Calmodulin (CaM) is a multifunctional intracellular calcium ion receptor protein that participates in a range of cellular processes, including calcium metabolism in mussels. To investigate the role of CaM in freshwater mollusk shell calcium metabolism, the full-length CaM cDNA was isolated from the freshwater pearl mussel, Hyriopsis schlegelii (referred to as $h s C a M$ ) using SMART RACE technology. The full-length $h s C a M$ was 855 bp in size, containing a 70-bp 5'-untranslated sequence, a 447-bp open reading frame, a 309-bp 3'-untranslated sequence, and a 26-nucleotide long poly(A) tail. The hsCaM mRNA expression in different mussel tissues was examined using real-time PCR. The $h s C a M$ mRNA was found to be ubiquitously expressed, but far more abundant in the gill, foot, and mantle than in the posterior adductor muscle. Real-time PCR was also used to determine hs CaM mRNA expression levels in mantle tissues of $H$. schlegelii at different ages. No significant differences between one-, two-, and threeyear-old mussels were detected, but expression increased in four-yearold mussels and then decreased in five-year-old mussels. CaM appears to be involved in calcium regulation of the mantle in four-year-old
\end{abstract}


mussels, which may secrete more mother of pearl during pearl culture.

Key words: Hyriopsis schlegelii; Calmodulin; Gene cloning; Nacre; Real-time polymerase chain reaction

\section{INTRODUCTION}

Calmodulin $(\mathrm{CaM})$ is a major intracellular calcium receptor present in many different cell types, and is one of the most conserved proteins among animals. CaM binds and regulates protein serine/threonine kinases in a calcium ion $\left(\mathrm{Ca}^{2+}\right)$-dependent manner. It participates in a range of cellular processes, including secretion, cell division and differentiation, DNA replication and repair, muscle contraction and glycogen metabolism, osmotic cell volume regulation, and intracellular communication (Cheung, 1980; Carafoli and Klee, 1999; Chin and Means, 2000; Feliciano and Edelman, 2009). In higher vertebrate species, CaM is encoded by multiple genes, such as CaM I, II, and III in humans (Fischer et al., 1988; Koller et al., 1990) and rats (Nojima, 1989) and CaM I and II in chickens (Putkey et al., 1983). However, the protein produced by the multiple genes in a vertebrate organism is always identical. The electric eel, which has two distinct sequences, is the exception to this rule (Lagace et al., 1983). The presence of different genes encoding exactly the same protein, all of which having a high basal expression, reflects the importance of this protein in the normal function of the cell. In lower vertebrates, invertebrates, and other groups, CaM is often encoded by a single gene with one identical amino acid sequence (e.g., the grass carp Ctenopharyngodon idellus (Huo et al., 2005), the mollusk Aplysia californica (Swanson et al., 1990), the crayfish Procambarus clarkii (Gao et al., 2009), and the fungus Aspergillus nidulans (Chen et al., 2010); the exception is the sea urchin Arbacia punctulata, with two distinct CaM cDNAs (Hardy et al., 1988).

The shells and pearls of bivalves are a biomineralization product of $\mathrm{CaCO}_{3}$ crystals, matrix protein, and other biopolymers (Wilbur, 1972; Mann, 2001). Formation of these products is the result of very complicated processes that are highly regulated by many physiological and biochemical activities, and more than 10 matrix proteins are involved in it (Marin et al., 2000; Zhang et al., 2003; Marin and Luquet, 2005; Takeuchi and Endo, 2006; Zhang and Zhang, 2006). Recently researches showed that among these regulatory factors, the extracellular $\mathrm{CaM}$ or CaM-like protein (CaMLP) and CaM or CaMLP-binding protein have been identified and believed to play an important role in extracellular process including biomineralization (Li et al., 2004; Yan et al., 2007). In marine bivalves, CaM mRNA is expressed at the folds and in the outer epithelial cells of the dorsal region of the mantle, where $\mathrm{Ca}^{2+}$ secretion takes place during shell formation ( $\mathrm{Li}$ et al., 2004). Thus, $\mathrm{Ca}^{2+}$ in bivalve animals is not only a regulatory agent involved in many physiological processes, but it is also the primary agent in the formation of shell structure (Addadi and Weiner, 1997; Li et al., 2004; Mount et al., 2004).

To date, many studies have focused on the CaM proteins of marine bivalves (e.g., the scallop Patinopecten (Toda et al., 1981), the mussel Mytilus edulis (Mimura et al., 1985), and the pearl oyster Pinctada fucata (Li et al., 2004)), but few studies about the freshwater bivalves, especially the freshwater pearl mussel Hyriopsis schlegelii, which originated from Lake Biwa in Japan and was introduced into China in 1998, is one of the representative freshwater pearl mussels. It has been widely applied in the Chinese freshwater pearl industry for its high-quality pearl bearing ability. To investigate the potential role of $\mathrm{CaM}$ in freshwater mollusk shell calcium metabolism, we isolated a full-length CaM cDNA from the freshwater pearl mussel $H$. schlegelii. We also examined CaM 
mRNA expression in different mussel tissues and in the mantle of different aged mussels using realtime PCR. Our results may provide some useful information about the complex mechanisms of $\mathrm{Ca}^{2+}$ accumulation, biomineralization, and pearl production in this freshwater pearl mussel.

\section{MATERIAL AND METHODS}

\section{Animal and RNA preparation}

Fifty H. schlegelii specimens of 1-5 years old (age based on shell growth lines) were collected from Fuzhou Hongmen Reservoir Exploitation Corporation Company, Jiangxi Province, China. The shell length of the five-year-old specimens was $30.08 \pm 2.33,98.87 \pm 12.25,123.72 \pm 11.90$, $152.02 \pm 10.38,160.03 \pm 10.44 \mathrm{~mm}$, respectively. Total RNA from the mantle was isolated using the SV Total RNA Isolation System (Promega, Madison, WI, USA). After the DNase treatment, the integrity and the quantity of RNA was determined by fractionation on $1.0 \%$ formaldehyde-denatured agarose gel and staining with ethidium bromide and a Biophotometer (Eppendorf, Hamburg, German). Total RNA ( $5 \mu \mathrm{g})$ extracted from mantle tissue was used to synthesize the first-strand cDNA using the SMART RACE cDNA Amplification Kit (Clontech, Mountain View, CA, USA).

\section{RACE analysis and cloning of CaM}

Sense $\left(\mathrm{F}_{1}\right)$ and antisense $\left(\mathrm{R}_{1}\right)$ primers were designed and synthesized based on the conserved regions of $\mathrm{CaM}$, including nearly all that were available from the National Center for Biotechnology Information website for marine bivalves. PCR was performed in a $25-\mu \mathrm{L}$ reaction mix containing $1 \mu \mathrm{L}$ mantle cDNA as the template DNA, $0.2 \mu \mathrm{M}$ of each primer, 0.5 U Ex Taq DNA polymerase (Takara, Dalian, China), $0.1 \mu \mathrm{M}$ of each dNTP, and $1 \mathrm{X}$ buffer for Taq polymerase. Amplification conditions were $94^{\circ} \mathrm{C}$ for $30 \mathrm{~s}, 55^{\circ} \mathrm{C}$ for $30 \mathrm{~s}$, and $72^{\circ} \mathrm{C}$ for $50 \mathrm{~s}$ for 35 cycles. A PCR fragment homologous to $\mathrm{CaM}$ was then used as the template for designing gene-specific RACE primers. 3'-RACE was performed using common SMART 3' primer and $\mathrm{F}_{2} / \mathrm{F}_{3}$ primers (Table 1), and 5'-RACE was performed using common SMART 5' primer and $\mathrm{R}_{2} / \mathrm{R}_{3}$ primer (Table 1). The PCR conditions for RACE were $94^{\circ} \mathrm{C}$ for $5 \mathrm{~min}, 94^{\circ} \mathrm{C}$ for $30 \mathrm{~s}$, and $72^{\circ} \mathrm{C}$ for $3 \mathrm{~min}$ for 5 cycles; $94^{\circ} \mathrm{C}$ for $30 \mathrm{~s} ; 70^{\circ} \mathrm{C}$ for $30 \mathrm{~s}$, and $72^{\circ} \mathrm{C}$ for $3 \mathrm{~min}$ for 5 cycles, and $94^{\circ} \mathrm{C}$ for $30 \mathrm{~s}, 68^{\circ} \mathrm{C}$ for $30 \mathrm{~s}$, and $72^{\circ} \mathrm{C}$ for 3 min for 30 cycles. All PCR products of the expected size were directly sub-cloned into PMD19-T vector (Takara) and sequenced using an ABI 3770 auto sequencer (ABI, Carlsbad, CA, USA).

Table 1. Primers for PCR amplification and analysis.
\begin{tabular}{ll}
\hline Primer & Sequence \\
\hline F1 & 5'-CAGAGGAGCAGATCGCAGAAT-3' \\
R1 & 5'-GTCCGTCACCGTCAATATCAG-3' \\
F2 & 5'-TGAGGTCTCTCGGACAGAACCAC-3' \\
F3 & 5'-CCCCACAGAGGCCGAGCTTCAGGACAT-3' \\
R2 & 5'-ACCTTCAACACAGCCAAGCTCGCAC-3' \\
R3 & 5'-GCAGCACTGATGAAGCCATTACCGT-3' \\
F4 & 5'-CAGAAGAACAAATTGCCGAAT-3' \\
R4 & 5'-GACCATCACCGTCAATATCAG-3' \\
F5 & 5'-GAGACCTTCAACACCCAGC-3' \\
R5 & 5'-GGACTCATCGTACTCCTGCTTG-3' \\
\hline
\end{tabular}




\section{Real-time PCR assay}

Total RNAs of mantle, posterior adductor muscle, foot, gill, and gonad samples from the 4-year-old specimens (age based on shell growth lines) were isolated using the TRIZOL ${ }^{\circledR}$ Reagent kit according to manufacturer instructions (Invitrogen, Carlsbad, CA, USA). In addition, the RNAs of mantle tissue from mussels aged 1 to 5 years were isolated. The quality and purity of the RNAs were checked by electrophoresis and the Biophotometer (Eppendorf). Isolated RNA was treated with DNAse I (Promega) prior to use for cDNA synthesis.

The RNAs were reverse-transcribed using M-MLV Reverse Transcriptase (RT) and oligo $(\mathrm{dT})_{18}$ (Promega) following the manufacturer protocol. Total volume for each reaction was $25 \mu \mathrm{L}$, and it contained $5 \mu \mathrm{g}$ of the total RNA, $0.5 \mathrm{mM}$ dNTP, $0.5 \mu \mathrm{M}$ oligo(dT) $)_{18}, 200$ U M-MLV RT, and $25 \mathrm{U}$ rRNasin ${ }^{\circledR}$ Ribonuclease Inhibitor with $1 \mathrm{X}$ M-MLV buffer $(10 \mathrm{mM}$ Tris- $\mathrm{HCl}, 25 \mathrm{mM} \mathrm{KCl}, \mathrm{pH} 8.3,0.6 \mathrm{mM} \mathrm{MgCl}_{2}$, and $2 \mathrm{nM}$ DTT). The reaction mixture was incubated at $42^{\circ} \mathrm{C}$ for $1 \mathrm{~h}$, terminated by incubation at $75^{\circ} \mathrm{C}$ for $15 \mathrm{~min}$, and samples were stored at $-80^{\circ} \mathrm{C}$. To minimize potential effects of differential synthesis during the RT reaction, three separate cDNA reactions were pooled for each RNA preparation analyzed. Two primers, sense $\left(\mathrm{F}_{4}\right)$ and antisense $\left(\mathrm{R}_{4}\right)$, were designed from fragments of the coding sequence corresponding to the $h s \mathrm{CaM}$ nucleotides. A fragment of the actin gene, a general housekeeping gene, was amplified as an internal control to check the integrity of the cDNA from the various tissues. The primers (F5 and R5) for the housekeeping gene were designed from the H. schlegelii $\beta$-actin (hs $\beta$-actin) gene (GenBank accession No. EU047596).

The reaction mixture $\left(25 \mu \mathrm{L}\right.$ in total) contained $1 \mathrm{X} \mathrm{SYBR}{ }^{\circledR}$ Premix EX Taq ${ }^{\mathrm{TM}}$ PCR Mix, $1 \mu \mathrm{L}$ template cDNA, and $0.2 \mu \mathrm{M}$ of each primer, with $\mathrm{ddH}_{2} \mathrm{O}$ added to reach $25 \mu \mathrm{L}$. Quantitative real-time PCRs were performed in a 96-well microtiter plate (ABI). Real-time PCR conditions were $95^{\circ} \mathrm{C}$ for 5 min for one cycle, followed by 35 cycles of $95^{\circ} \mathrm{C}$ for $30 \mathrm{~s}$, $55^{\circ} \mathrm{C}$ for $30 \mathrm{~s}$, and $72^{\circ} \mathrm{C}$ for $30 \mathrm{~s}$. A Roche Light Cycler 480 (Roche, Hoffmann, Switzerland) was used. The cDNA samples were diluted in 2-, 4-, 16-, 64-, and 256-fold, and the standard curves were created to determine the PCR efficacy of each primer pair based on these folds. In this study, the $2^{-\Delta \Delta \mathrm{Ct}}$ method of relative quantification was adapted to estimate fold change in expression of $h s \mathrm{CaM}$. Relative quantification was performed by normalizing the $\mathrm{Ct}$ values of each sample gene with the $\mathrm{Ct}$ value of the endogenous control $\beta$-actin gene $\left({ }^{\Delta} \mathrm{Ct}\right)$ and then using ${ }^{\Delta} \mathrm{Ct}$ of the control tissue/age as a calibrator. ${ }^{\Delta \Lambda} \mathrm{Ct}$ corresponds to the difference between the ${ }^{\Delta} \mathrm{Ct}$ of the gene of interest and the ${ }^{\Delta} \mathrm{Ct}$ of the endogenous control. A melting curve was constructed to ensure that only a single PCR product was amplified. Samples were assayed in triplicate, and each experiment was repeated at least three times. Negative and positive control reactions (without template or Taq enzyme) were performed for each sample.

\section{RESULTS}

\section{Cloning of a full-length cDNA encoding a CaM gene from $\mathrm{H}$. schlegelii}

A 380-bp cDNA fragment of $h s C a M$ was obtained from mantle tissue of $H$. schlegelii by RT-PCR using the primers F1 and R1. Based on this 380-bp partial sequence, the fulllength cDNA encoding $h s \mathrm{CaM}$ was obtained using a pair of gene-specific primers. Touchdown PCR with 5'-RACE yielded a 440-bp fragment, whereas 3'-RACE yielded a 690-bp fragment. 
Figure 1 shows the complete nucleotide sequence and deduced amino acid sequence from $H$. schlegelii mantle tissue. The full-length $h s C a M$ was $855 \mathrm{bp}$, which consists of a 447-bp open reading frame, a 70-bp non-coding region at the 5 ' terminal, and a 309-bp non-coding region with a poly(A) tail 26 nucleotides long at the $3^{\prime}$ terminus. A putative polyadenylation signal (AATAAA) lies at nucleotide position 810, which is 13 nucleotides upstream of the poly(A) tail, and two mRNA destabilizing motifs (ATTTTA) are present at positions 629 and 661. This cDNA sequence has been submitted to GenBank with the accession No. FJ194962.

ACAACATTGG 10

AATCTGGTTAGATAGATTTTTAAATTTGAGAGCGGCAAATCAAAGAAACTGCAATCCGCG 70

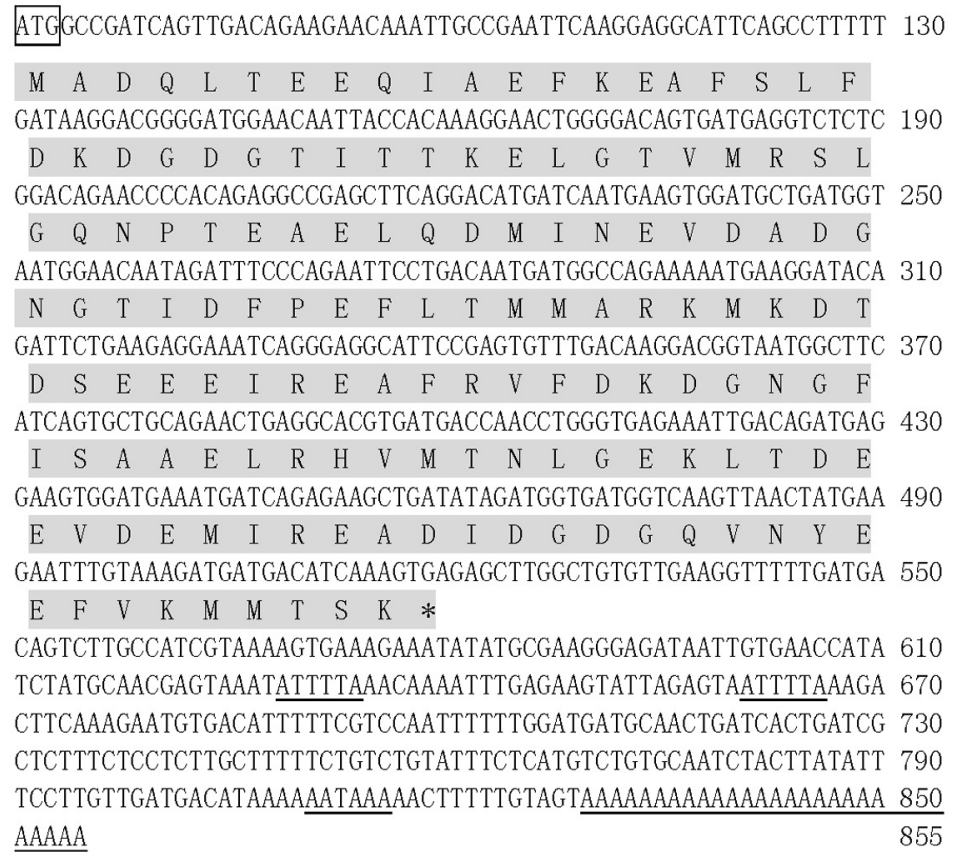

Figure 1. Full-length cDNA and predicted protein sequence of the Hyriopsis schlegelii CaM gene from the mantle. Nucleotides and amino acids are numbered to the right of the sequence. The initiator codon (ATG) is shown in the square, and the stop codon (TGA) is indicated by an asterisk. The poly-A-tailed signal, putative polyadenylation signal (AATAAA) and mRNA destabilizing motifs (ATTTTA) are underlined, and the amino acids are in the shaded area.

\section{Sequence analysis of $h s \mathrm{CaM}$ protein}

The deduced $h s \mathrm{CaM}$ protein consists of 149 amino acids with a calculated molecular mass of $16.8 \mathrm{kDa}$ and an isoelectric point of 4.14. Like other mollusks and invertebrate $\mathrm{CaM}$ proteins, the $h s \mathrm{CaM}$ protein did not contain the amino acids cysteine and tryptophan. A translated query-protein database BLAST search revealed that this deduced 149 amino acid sequence of $h s \mathrm{CaM}$ matched exclusively with published CaMs, including those from invertebrate and vertebrate species. Multiple protein sequence alignment analysis (Figure 2) showed that the $h s \mathrm{CaM}$ sequence shares high similarity with other CaMs isolated from invertebrate 
and vertebrate animals. Only three residues $\left(\mathrm{Phe}^{100}\right.$, Lys ${ }^{144}$, and $\left.\mathrm{Ser}^{148}\right)$, which were concentrated mainly at the carboxyl terminus, differed from the vertebrate CaMs. Compared with other invertebrates, the $h s \mathrm{CaM}$ differed from that of Patinopecten sp (Toda et al., 1981) by three residues $\left(\mathrm{Asp}^{61}, \mathrm{Asp}^{97}\right.$, and $\left.\mathrm{Thr}^{144}\right)$, from that of A. californica (Swanson et al., 1990) and P. fucata (Li et al., 2004), but only by the $\mathrm{Thr}^{144}$ and $\mathrm{Thr}^{147}$ residues, respectively. However, the hs CaM is identical with the CaM from Metridium senile (Yuasa et al., 2001).

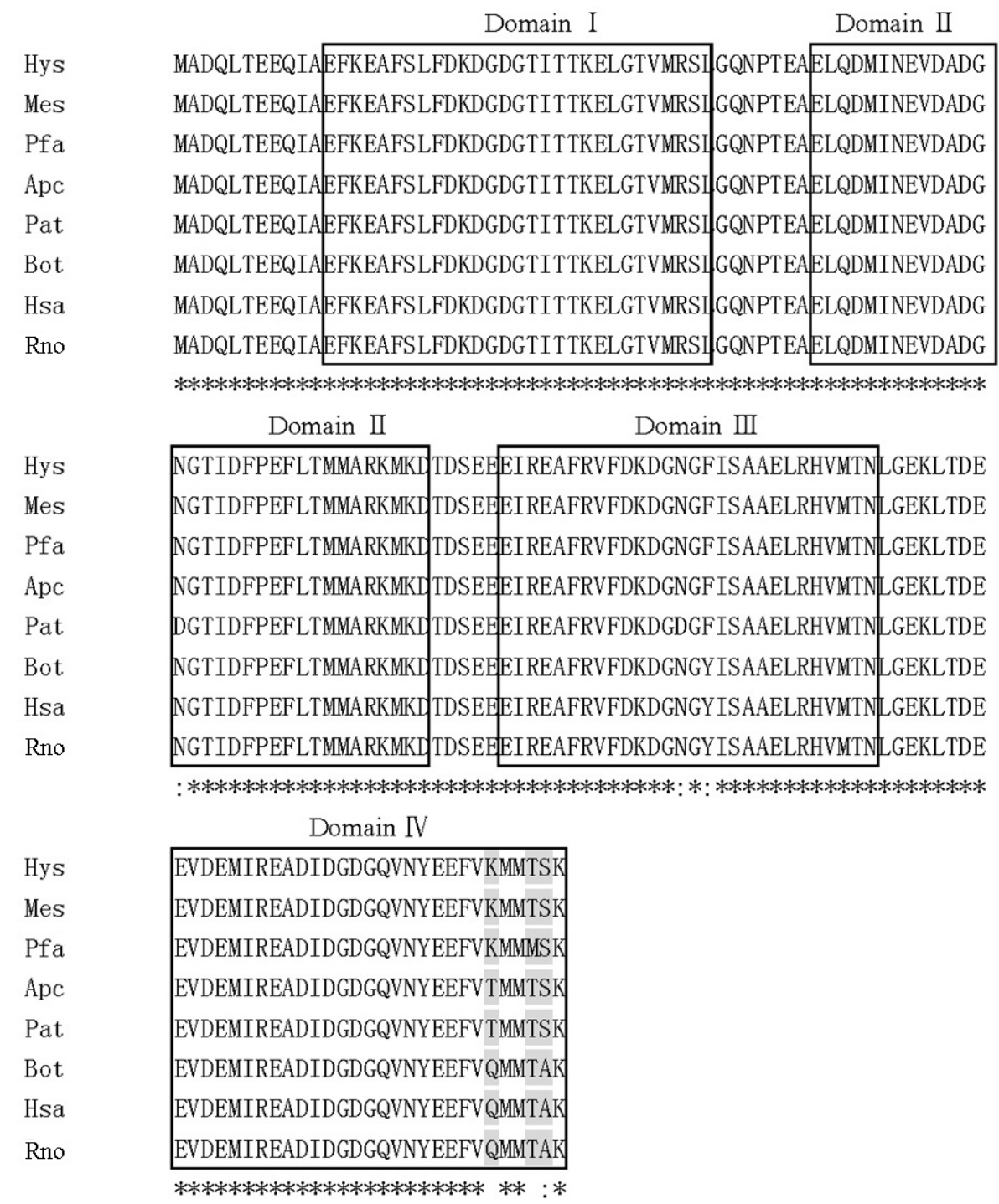

Figure 2. Alignment of the sequence of Hyriopsis schlegelii CaM with other CaMs from invertebrates and vertebrates. Domains I, II, III, and IV stand for the four EF-hand domains. Hys = Hyriopsis schlegelii, FJ194962; Mes = Metridium senile, BAB61796; Pfa = Pinctada fucata, AY341376; Apc = Aplysia californica, CAA40207; Pat = Patinopecten $\mathrm{sp,}$ P02595; Bot $=$ Bos taurus, P62157; Hsa = Homo sapiens, $\mathrm{P} 02593 ;$ Rno $=$ Rattus norvegicus, CAA32119. 
The amino acid sequence of $\mathrm{CaM}$ contains four putative $\mathrm{Ca}^{2+}$ binding EF-hand domains (I, II, III, and IV) (Figure 2), as predicted from the Protein Families database of the Sanger Institute (Pfam 24.0; Anonymous, 2011), and they exhibit a sequence homology with one another. Each domain is composed of 12 amino acid residues, 6 of which serve as ligands for $\mathrm{Ca}^{2+}$ in the metal-protein complex (e.g., aspartic acid (D) and glutamate (E)).

\section{Real-time PCR assay for hsCaM mRNA expression}

The melting curve analysis results were performed and resulted in single-productspecific melting temperatures as follows: $h s C a M, 85.2^{\circ} \mathrm{C}$ and $h s \beta$-actin, $84.9^{\circ} \mathrm{C}$. No primerdimers were generated during the applied 35 real-time PCR amplification cycles. The standard curves showed the PCR efficacies of each primer pair, which were between 1.923 and 1.986.

Real-time PCR data revealed a dynamic regulation of $h s C a M$ mRNA relative to the $\beta$-actin gene in $H$. schlegelii. Tissue differential expression showed that $h \mathrm{CaM}$ was broadly distributed in all tissues tested (mantle, posterior adductor muscle, foot, gill, and gonad) (Figure 3); the expression levels were dramatically higher in the gill. Using the posterior adductor muscle $\mathrm{CaM}$ expression value as a calibrator to determine the relative expression levels of $\mathrm{CaM}$ in other tissues, the highest $C a M$ mRNA expression levels were found in the gill (106.00 \pm 8.08 -fold), followed by foot ( $72.88 \pm 6.99$-fold), mantle ( $63.72 \pm 5.48$-fold), and gonad ( $10.5 \pm 4.77$-fold).

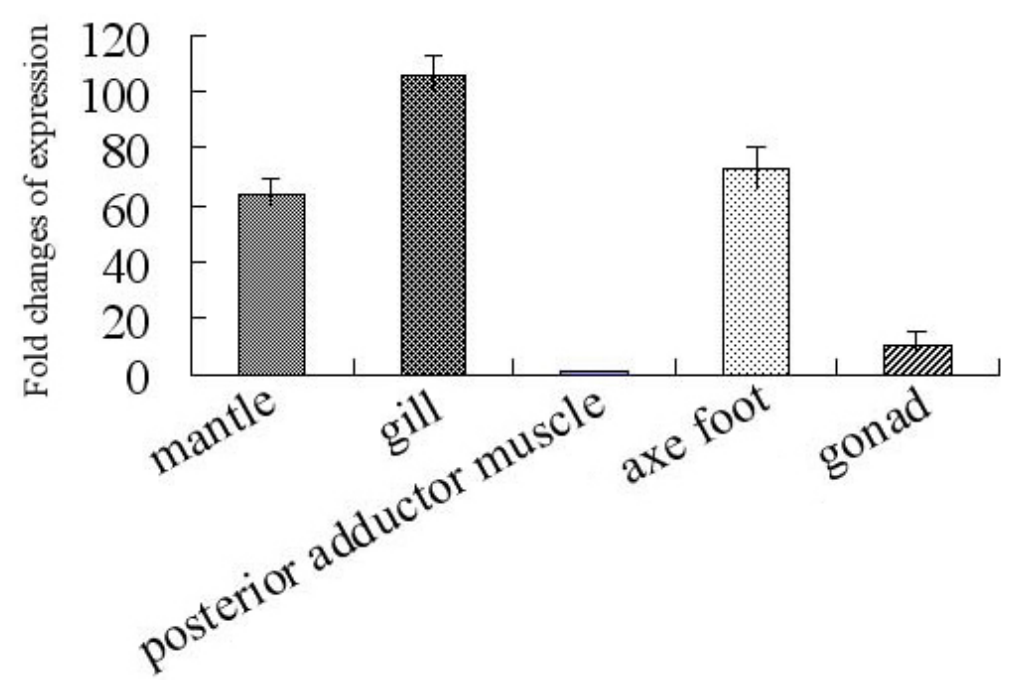

Figure 3. CaM gene expression in different tissues of Hyriopsis schlegelii.

Figure 4 shows the real-time PCR results of $h s C a M$ mRNA expression in mantle tissue from mussels of different ages. Similar expression levels were observed in 1- to 3-year-old mussels; the expression level was the lowest in 1-year-old mussels (used as the calibrator) and did not increase significantly over the next 2 years (1.12 \pm 0.21 -fold, $1.15 \pm 0.40$-fold). Compared to the expression level of 1-year-old mussels, hsCaM mRNA expression in 4-year-old mussels was 3.10 \pm 0.39 -fold higher and in 5-year-old mussels it was $1.60 \pm 0.35$-fold higher. 


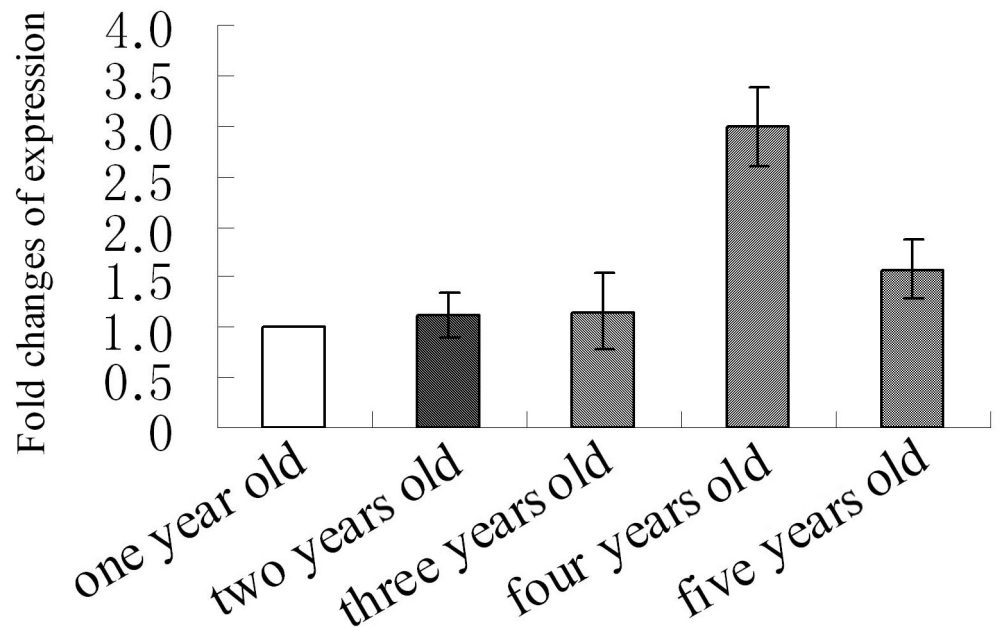

Figure 4. CaM gene expression in mantle tissues of Hyriopsis schlegelii of different ages.

\section{DISCUSSION}

Recent studies have shown that $\mathrm{CaM}$ is a pivotal calcium metabolism regulator, also regulated by many other calcium metabolism-related proteins (Chamberlain et al., 1995; Hoeflich and Ikura, 2002; Catalano and O'Day, 2008) and that it plays an important role in the shell formation process of the pearl oyster (Takeuchi and Endo, 2006; Huang et al., 2007). In this study, we cloned a CaM gene from the mantle of $H$. schlegelii using PCR and SMART RACE, and we also examined the expression of CaM mRNA in different tissues and in mussels of different ages using real-time PCR.

The deduced primary amino acid sequence of $h s \mathrm{CaM}$ (Figure 2 ) shows high identity with the published CaMs of a range of invertebrate (99\%) and vertebrate $(98 \%)$ species. Compared to the marine pearl oyster $P$. fucata CaM, there is a single-amino acid substitution at position 147, which is occupied by a Thr in H. schlegelii and a Met in P. fucata. The Met at this position in P. fucata was considered to be a characteristic residue of the oyster (Li et al., 2004), but it was not found in the freshwater pearl mussel. The CaM genes from different vertebrate species encode the same CaM molecule with identical amino acid sequences, suggesting its high conservation during vertebrate evolution. In this study, we found that the $h s \mathrm{CaM}$ protein from $H$. schlegelii was identical to that from Metridium senile (Yuasa et al., 2001), which indicates that the CaM proteins were highly conserved during invertebrate evolution.

The high degree of homology observed within the nucleotide sequence of domains I and III (53.6\%) and domains II and IV (44.8\%) supports the theory of gene duplication in a manner similar to that hypothesized for the chicken ovomucoid gene (Putkey et al., 1983). Comparison of the amino acid composition of the calcium-binding domains in canonical EFhands with the same domains in oyster (Li et al., 2004) suggested that the portions of the molecule, which participate in calcium binding, will be more highly conserved than other portions.

Among the various parts of $H$. schlegelii tested, gill tissue had the highest level of $h s \mathrm{CaM}$ mRNA, which was also observed in P. fucata (Li et al., 2004). The quantity of CaM mRNA in gill 
tissue was $106 \pm 8.08$-fold higher than that in the posterior adductor muscle. In bivalves, the gill is the primary organ for calcium uptake from the water (Elijah, 1984; Rousseau et al., 2003). Particularly in the scallop, the gill is thought to play a regulatory role in the membrane $\mathrm{Ca}^{2+}$-ATPase system or to act as a "calcium sink" (Stommel et al., 1982). The high expression level of hsCaM mRNA in the gill supports the theory that CaM plays an important regulatory role in calcium uptake and accumulation in the gill of $H$. schlegelii. The original hypotheses about CaM posited that CaM expression would be greater in epithelial tissues (such as the gill and mantle) and lesser in non-epithelial tissues (such as muscle) (Wheatly, 1999). Contrary to the prediction, CaM was more abundant in the foot (muscle tissue) than the gill (epithelial tissue) of $H$. schlegelii, which has also been reported in the muscle of $P$. fucata (Li et al, 2004). At the same time, we found that the mRNA level in $H$. schlegelii was high in the foot but very low in posterior adductor muscle (the calibrator), according to the hypotheses (Wheatly, 1999) there may be muscle-type CaMs assisted in foot tissue. Based on the prior studies of CaMs in the freshwater species, such as goldfish (Huo et al., 2004), carp (Huo et al., 2005), crayfish (Gao et al., 2009), the different tissue-specific expression profiles indicated that more CaMs participate in mineralization processes of the aquatic animals.

In mollusks, the mantle, especially the outer epithelium of the mantle, plays a key role in shell formation (Wilbur, 1972; Yan et al., 2007). The precise expression sites of $P$. fucata CaM mRNA in the mantle were the inner epithelial cells of the outer fold, the outer epithelial cells of the middle fold, and the outer epithelial cells of the inner fold (Li et al., 2004). In our study, the $h s C a M$ mRNA expression level was $63.72 \pm 5.48$-fold higher in the mantle compared to the posterior adductor muscle, which is similar to results reported for other animals (Li et al., 2004).

A major objective of the present study was to determine the relative expression of CaM in the mantle among mussels of different ages. We found no significant differences in CaM mRNA expression level in the mantle among 1-, 2-, and 3-year-old mussels, whereas 4- and 5-year-old mussels exhibited higher expression ( $3.10 \pm 0.39$-fold and $1.60 \pm 0.35$-fold higher than 1-year-old mussels, respectively). Pearl formation is a complex process that involves the uptake, transport, and recruitment of $\mathrm{Ca}^{2+}$. Our results suggest that more CaM is involved in calcium regulation of the mantle in 4-year-old mussels, which may secrete more nacre during pearl culture.

In conclusion, we cloned the full-length CaM gene cDNA from the mantle of the freshwater mussel $H$. schlegelii and found it to be widely expressed in many tissues. Real-time PCR results also indicated a similar level of mRNA expression among 1-, 2-, and 3-year-old mussels, an increase in 4-year-old mussels, and a decrease in 5-year-old mussels.

Continued studies in $\mathrm{H}$. schlegelii should search for the possible existence of CaMlike protein known to be expressed in other species in biomineralization (Yan, et al 2007) and the multiple transcripts of CaM known to be expressed in other species (Huo et al., 2005). As part of an ongoing research program for freshwater pearl culture, we propose to examine CaM expression in response to artificial inducing in pearl culture, such as the number and the size of the mantle piece in nucleated pearl cultivation. The observation in the present study that $\mathrm{CaM}$ is expressed in 4-year-old mussel will be the start of a program to assess the CaM expression during the lifespan. Further research is warranted regarding the detailed mechanisms of calcium channels, calcium pump, and CaM-dependent protein kinase.

\section{ACKNOWLEDGMENTS}

Research supported by the Special Fund for Agro-Scientific Research in the Public In- 
terest (\#200903028), the 948 Program of the Ministry of Agriculture of China (\#2004-T9), the National Natural Science Foundation of China (\#31160534), the Research Foundation of the Education Bureau of Jiangxi Province (2009), and the Key Science and Technology Program of Jiangxi Province, China (2008).

\section{REFERENCES}

Addadi L and Weiner S (1997). Biomineralization: a pavement of pearl. Nature 389: 912-915.

Anonymous (2011). Protein Families Database from the Sanger Institute (Pfam 24.0). Available at [http://pfam.sanger. ac.uk/search]. Accessed February 19, 2011.

Carafoli E and Klee CB (1999). Calcium as a Cellular Regulator. Oxford University Press, New York.

Catalano A and O'Day DH (2008). Calmodulin-binding proteins in the model organism Dictyostelium: a complete and critical review. Cell Signal. 20: 277-291.

Chamberlain LH, Roth D, Morgan A and Burgoyne RD (1995). Distinct effects of alpha-SNAP, 14-3-3 proteins, and calmodulin on priming and triggering of regulated exocytosis. J. Cell Biol. 130: 1063-1070.

Chen S, Song Y, Cao J, Wang G, et al. (2010). Localization and function of calmodulin in live-cells of Aspergillus nidulans. Fungal Genet. Biol. 47: 268-278.

Cheung WY (1980). Calmodulin plays a pivotal role in cellular regulation. Science 207: 19-27.

Chin D and Means AR (2000). Calmodulin: A prototypical calcium sensor. Trends Cell Biol. 10: 322-328.

Elijah WS (1984). Calcium activation of mussel gill abfrontal cilia. J. Comp. Physiol. 155: 457-469.

Feliciano DM and Edelman AM (2009). Repression of $\mathrm{Ca}^{2+} /$ calmodulin-dependent protein kinase IV signaling accelerates retinoic acid-induced differentiation of human neuroblastoma cells. J. Biol. Chem. 284: 26466-26481.

Fischer R, Koller M, Flura M, Mathews S, et al. (1988). Multiple divergent mRNAs code for a single human calmodulin. J. Biol. Chem. 263: 17055-17062.

Gao Y, Gillen CM and Wheatly MG (2009). Cloning and characterization of a calmodulin gene (CaM) in crayfish Procambarus clarkii and expression during molting. Comp. Biochem. Physiol. B Biochem. Mol. Biol. 152: 216-225.

Hardy DO, Bender PK and Kretsinger RH (1988). Two calmodulin genes are expressed in Arbacia punctulata. An ancient gene duplication is indicated. J. Mol. Biol. 199: 223-227.

Hoeflich KP and Ikura M (2002). Calmodulin in action: diversity in target recognition and activation mechanisms. Cell 108: 739-742.

Huang J, Zhang C, Ma Z, Xie L, et al. (2007). A novel extracellular EF-hand protein involved in the shell formation of pearl oyster. Biochim. Biophys. Acta 1770: 1037-1044.

Huo L, Lee EK, Leung PC and Wong AO (2004). Goldfish calmodulin: molecular cloning, tissue distribution, and regulation of transcript expression in goldfish pituitary cells. Endocrinology 145: 5056-5067.

Huo L, Fu G, Wang X, Wendy KW Ko, et al. (2005). Modulation of calmodulin gene expression as a novel mechanism for growth hormone feedback control by insulin-like growth factor in grass carp pituitary cells. Endocrinology 146: 3821-3835

Koller M, Schnyder B and Strehler EE (1990). Structural organization of the human CaMIII calmodulin gene. Biochem. Biophys. Acta 1087: 180-189.

Lagace L, Chandra T, Woo SL and Means AR (1983). Identification of multiple species of calmodulin messenger RNA using a full length complementary DNA. J. Biol. Chem. 258: 1684-1688.

Li S, Xie L, Zhang C, Zhang Y, et al. (2004). Cloning and expression of a pivotal calcium metabolism regulator: calmodulin involved in shell formation from pearl oyster (Pinctada fucata). Comp. Biochem. Physiol. B Biochem. Mol. Biol. 138: 235-243.

Mann S (2001). Biomineralization: Principles and Concepts in Bioinorganic Materials Chemistry. Oxford University Press, New York.

Marin F and Luquet G (2005). Molluscan biomineralization: The proteinaceous shell constituents of Pinna nobilis L. Mater. Sci. Eng. C 25: 105-111.

Marin F, Corstjens P, de Gaulejac B, de Vrind-De JE, et al. (2000). Mucins and molluscan calcification. Molecular characterization of mucoperlin, a novel mucin-like protein from the nacreous shell layer of the fan mussel Pinna nobilis (Bivalvia, pteriomorphia). J. Biol. Chem. 275: 20667-20675.

Mimura T, Yamanobe T and Sugi H (1985). Isolation and characterization of calmodulin from a molluscan smooth muscle. Comp. Biochem. Physiol. B 81: 559-563.

Mount AS, Wheeler AP, Paradkar RP and Snider D (2004). Hemocyte-mediated shell mineralization in the eastern oyster. 
Science 304: 297-300.

Nojima H (1989). Structural organization of multiple rat calmodulin genes. J. Mol. Biol. 208: 269-282.

Putkey JA, Ts'ui KF, Tanaka T, Lagace L, et al. (1983). Chicken calmodulin genes. A species comparison of cDNA sequences and isolation of a genomic clone. J. Biol. Chem. 258: 11864-11870.

Rousseau M, Plouguerne E, Wan G, Wan R et al. (2003). Biomineralization markers during a phase of active growth in Pinctada margaritifera. Comp. Biochem. Physiol. 135: 271-278.

Stommel EW, Stephens RE, Masure HR and Head JF (1982). Specific localization of scallop gill epithelial calmodulin in cilia. J. Cell Biol. 92: 622-628.

Swanson ME, Sturner SF and Schwartz JH (1990). Structure and expression of the Aplysia californica calmodulin gene. J. Mol. Biol. 216: 545-553.

Takeuchi T and Endo K (2006). Biphasic and dually coordinated expression of the genes encoding major shell matrix proteins in the pearl oyster Pinctada fucata. Mar. Biotechnol. 8: 52-61.

Toda H, Yazawa M, Kondo K, Honma T, et al. (1981). Amino acid sequence of calmodulin from scallop (Patinopecten) adductor muscle. J. Biochem. 90: 1493-1505.

Wheatly MG (1999). Calcium homeostasis in crustacea: the evolving role of branchial, renal, digestive and hypodermal epithelia. J. Exp. Zool. 283: 620-640.

Wilbur KM (1972). Shell Formation in Mollusks. In: Chemical Zoology, VII (Florkin M and Scheer BT, eds.). Academic Press, New York, 243-282.

Yan Z, Fang Z, Ma Z, Deng J, et al. (2007). Biomineralization: functions of calmodulin-like protein in the shell formation of pearl oyster. Biochim. Biophys. Acta 1770: 1338-1344.

Yuasa HJ, Suzuki T and Yazawa M (2001). Structural organization of lower marine nonvertebrate calmodulin genes. Gene 279: 205-212.

Zhang C and Zhang R (2006). Matrix proteins in the outer shells of molluscs. Mar. Biotechnol. 8: 572-586.

Zhang Y, Xie L, Meng Q, Jiang T, et al. (2003). A novel matrix protein participating in the nacre framework formation of pearl oyster, Pinctada fucata. Comp. Biochem. Physiol. B Biochem. Mol. Biol. 135: 565-573. 